\title{
Natural enemies of pentatomids affecting rice fields in Puerto Rico'
}

\author{
Rosa A. Franqui, Alberto Pantoja, Silverio Medina Gaud ${ }^{2}$
}

\begin{abstract}
Parasitoids were recovered from adults and egg masses of Mormidea angustata Stål and Oebalus ypsilon-griseus (De Geer). Three parasitoid species were recovered; the species were identified as Beskia aelops Walker (Dipłera:Tachinidae), Gymnodytia sp. (Diptera:Tachinidae), Ooencyrtus submefallicus Howard (Hymenoptera:Encyrtidae).

\section{RESUMEN}

Enemigos naturales de los pentatómidos de los arrozales de Puerto Rico

Se recobraron parasitoides de los adultos y masas de huevos de Mormidea angustata Stål y Oebalus ypsilon-griseus (De Geer). Tres especies de parasitoides se recuperaron: se identificaron como Beskia aelops Walker (Diptera: Tachinidae), Gymnoclytia sp. (Diptera: Tachinidae), Ooencyrtus submetallicus Howard (Hymenoptera: Encyrtidae).
\end{abstract}

\section{INTRODUCTION}

Little is known about the parasitoids of pentatomids attacking rice fields. Two hymenopteran species, Ooencyrtus anasae (Ashmead) (Hymenoptera:Encyrtidae) and Telenomus podissi Ashmead (Hymenoptera: Scelionidae), are known to attack Oebalus pugnax (F.) eggs recovered from rice plants $(6,11)$. These parasitoids are important factors in reducing natural stinkbug populations in rice fields, especially during the late season $(4,6,9,10)$.

Thames (12) reported Beskia aelops (Walker) (Diptera:Tachinidae) parasitizing $O$. pugnax adults recovered from rice fields in Florida. Wolcott (13) reported the introduction of four species of tachinids from Chile to Puerto Rico, without listing the species introduced. Under laboratory conditions the introduced tachinids attacked Mormidea angustata Stål,

${ }^{1}$ Manuscript submitted to Editorial Board 23 Febmary 1988.

"Research Assistant, Assistant Entomologist and Entomologist, Department of Crop Protection, Agricultural Experiment Station, Mayagüez Campus, Univ. P. R., Río Piedras, P. R.

This research was supported by the U. S. Department of Agriculture under CRSR Special Grant No. 85-CRSR-2-2665 titled "Varietal resistance to insect pests of rice in the Caribbean Basin" Managed by the Caribbean Basin Advisory Group (CBAG) and by H-285 Project. The authors express appreciation to A. Armstrong, E. Abreu, C. Cruz and A. Segarra for eritical review of the manuscript. 
Mormidea ypsilon Sailer, and O. pugnax, but development was not completed in these pentatomids species (1).

In Puerto Rico chemical control is the main tactic for stinkbug management in rice fields, whereas very little attention has been given to the use of natural enemies as control agents. No parasitoids have been reported for pentatomids infesting rice fields in Puerto Rico. The research reported here was initiated in an effort to identify stinkbugs' natural enemies in Puerto Rico rice fields.

\section{MATERIALS AND METHODS}

Adult pentatomids were collected from rice fields at Arecibo, Lajas, Manatí, and Vega Baja. A total of 389 samples were examined during a 6 -month study. Sampling began 4 to 5 hours after sunrise. Each field was sampled weekly with a standard insect net (38.1 cm diameter). Each sample consisted of 100 ramdomly cast sweeps. Each horizontal stroke with the net in either direction was considered as one sweep. One sweep was completed with each forward step. Sampling began at least $10 \mathrm{~m}$ into the field from the roadside, and was centered between the field levees to avoid possible edge effects $(4,7)$. Insects were placed in plastic bags and brought to the laboratory inside a plastic cooler. Stinkbug species were separated, counted, and placed in small aluminum sereen cages $(0.3$ $\times 0.3 \times 0.3 \mathrm{~m}$ ).

Insects were fed the Jones et al. Oncopeltus fasciatus diet (8), but sunflower seed was replaced by field-collected rice kernels. Insects were monitored daily for mortality and/or parasitoid emergence. Puparia were placed individually in $30-\mathrm{ml}$ plastic containers supplied with moist vermiculite.

Stinkbug egg masses observed on rice plants were hand collected and taken to the laboratory. Masses were placed in petri dishes $(100 \times 15$ $\mathrm{mm}$ ) supplied with a moistened filter paper (Whatman \#3). The dishes were examined daily and water was supplied as needed until parasitoids emerged. Both adults and egg masses were kept under laboratory conditions (14:10 light:dark cycle, $29^{\circ} \mathrm{C}$ ).

Adult parasitoids were identified by N. E. Woodley (Diptera) and R. W. Carlson (Hymenoptera) of the USDA Beneficial Insect Identification and Systematic Institute (BIISI) at Beltsville, Maryland. Voucher specimens were deposited at the Entomology Museum of the Crop Protection Department, Agricultural Experiment Station, Río Piedras, Puerto Rico. The voucher specimens were identified as Beskia aelops (Walker), PR Ac. No. 367-86; 412-86, Gymnoclytia sp., PR Ac. No. 368-86, Ooencyrtus submetallicus (How.), PR Ac. No. 495-86.

\section{RESULTS AND DISCUSSION}

A total of 172 parasitoids were recovered from a total of 12,749 pentatomids and $21 \mathrm{egg}$ masses observed. Eleven were identified as Beskia 
aelops Walker, (Diptera:Tachinidae), 71 as Gymnoclytia sp. (Diptera: Tachinidae) and 90 as Ooencyrtus submetallicus Howard (Hymenoptera: Encyrtidae). Species of Gymnoclytia are not identifiable (R. W. Carison, BIISI, personal communication). Beskia aelops was previously reported $(2,11,12)$ parasitizing $O$. pugnax adults collected from rice fields in the United States.

In our study $B$. aelops was recovered from $M$. angustata and $O$. ypsilon-griseus, but not from $M$. cubrosa, $O$. pugnax, or $O$.grisescens. Arnaud (2) listed Euchistus ictericus (L.), Mormidea pictiventris Stål, Nezara viridula (L.), and $O$. pugnax as hosts of $B$. aelops. Our findings are the first report of $B$. aelops parasitizing $M$. angustata and $O$. ypsilongriseus in Puerto Rico. Furthermore, this is the first report of any parasite affecting $M$. angustata and $O$. ypsilon-griseus recovered from rice fields.

Mormidea angustata and $O$. ypsilon-griseus egg masses were parasitized by 0 . submetallicus. This is the first time 0 . submetallicus has been recovered from pentatomid egg masses in Puerto Rico and from pentatomid eggs collected from rice plants. In the United States, Ingram (6) listed $O$. anasae and $T$. podissi as parasitoids of $O$. pugnax eggs collected from rice fields. Gahan (5) reported the recovery of 0 . submetallicus from $N$. viridula eggs collected from the island of St. Vineent without indicating the host plant from which the pentatomid eggs were collected. During 1961-63, O. submetallicus was introduced to Hawaii (3) for $N$. viridula control, but the parasite was not recovered from the field and $O$. submetallicus effectiveness in controlling natural stinkbug populations is still unknown. The low percentage of pentatomids affected by B. aelops $(0.09 \%)$ and Gymnoclytia sp. $(0.56 \%)$, suggests that parasitoids could be of little importance in controlling their populations in Puerto Rico. Additional studies are needed to establish the effectiveness of $B$. aelops, Gymnoclytia sp., and U. submetallicus in controlling pentatomid populations in Puerto Rico rice fields. Future research to determine parasitoid host range, abundance, and bionomics is needed to establish their potential as biological control agents in integrated pest management (IPM) programs.

\section{LITERATURE CITED}

1. Anonymous, 1942. Monthly Reports Mayaguez Exp. Stn., USDA Fiscal Year 1940-41: 23.

2. Arnaud, P. H., 1978. A host parasite catalog of North American Tachinidae (Diptera). USDA Mise. Publ, 319: 92-3.

3. Davis, C. J., 1964. The introduction, propagation, liberation, and establishment of parasites to control Nezara viridula variety samaragdula (Fabricius) in Hawail (Heteroptera:Pentatomidae), Proc. Hawaii. Entomol. Soc. 18 (3): 369-75.

4. Douglas, W. A. and J. W. Ingram, 1942. Rice field insects. USDA Circ. 632: 2-7.

5. Gahan, A. B., 1927. Miscellaneous deseriptions of new parasitic Hymenoptera with some synonymical notes. U.S. Natl. Mus. Proc. 2676: 15-7. 
6. Ingram, J. W., 1927. Insects injurious to the rice crop. U.S. Dep. Agric. Farmers Bull. 1543: $1-4$.

7. Jones, D. B, and R. H. Cherry, 1986. Species composition and seasonal abundance of stink bugs (Heteroptera:Pentatomidae) in southern Florida rice, J. Econ. Entomol. 79: $1226-229$.

8. Jones, G. L., J. V. Mei and C. H. Yin, 1986. Meridic diet for Oncopeltus fasciatus (Hemiptera:Lygreidae) and its utilization in evaluating an insect growth regulator. J. Econ. Entomol. 79: 323-28.

9. Odglen, G. E. and L. D. Warren, 1962. The rice stink bug Oebalus pugnax (F.) in Arkansas. Arkansas Agric. Exp. Stn. Rep. Ser. No. 107. (Abstract).

10. Smith, C. M., J. L. Bagent, S. D. Liscombe and J. F. Robinson, 1986. Insect pests of rice in Louisiana. La. Agric. Stn, Bull. 774.

11. Swanson, M. C., 1960. Rice stinkbug. In Insects conditions in Louisiana. 3: 10.

12. Thames, W. H., Jr., 1954. Insects investigations. Fla. Agric. Exp. Stn. Ann. Rep. 1954: 236.

13. Wolcott, G. N., 1948. The insects of Puerto Rico. J. Agric. Univ. P. R. 32: 778. 